\title{
EMPOWERMENT OF LOCAL BRAND AWARENESS THROUGH PACKAGING UNIQUENESS AND ITS IMPACT ON PURCHASING INTEREST
}

\author{
Bob Foster ${ }^{1}$, Wawan Hermawan ${ }^{2}$, Rima Rahmayanti ${ }^{3}$ \\ ${ }^{1}$ Fakultas Ekonomi dan Bisnis Universitas Bisnis dan Informatika Bandung, Kota Bandung 40285 \\ ${ }^{2}$ Fakultas Ekonomi, Universitas Langlangbuana, Jl. Karapitan No.116, Kota Bandung, 40261 \\ ${ }^{3}$ Fakultas Bisnis \& Manajemen, Universitas Widyatama, Jl. Cikutra No.204A, Kota Bandung, 40125 \\ bobriset@unibi.ac.id \\ Received: 4 Desember 2018 \\ Revised: 16 Januari 2019 \\ Accepted: 18 Januari 2019
}

\begin{abstract}
Indonesian local brand is lack of brand awareness among Indonesian consumers. One of the local brands that lack of brand awareness is white tea brand. White tea makers in Indonesia meets the issue of absence of innovation in packaging, shopper awareness and frailness in quality. This research aims to test whether product empowerment and brand awareness will influence the interest in buying white tea products with unique packaging as intervening using partial least square as method in data analysis. Data collection uses questionnaire involving 50 consumer samples of white tea brand in Bandung, West Java. This research shows that the uniqueness of packaging has proven to be intervention between brand awareness and empowerment in product, affects or influences the consumer purchasing interest of white tea brand in Bandung, West Java, Indonesia.
\end{abstract}

Keywords: local product, brand awareness, packaging uniqueness

Abstrak: Merek lokal Indonesia mengalami kekurangan kesadaran merek di kalangan konsumen Indonesia. Salah satu merek lokal yang kurang kesadaran mereknya adalah merek teh putih. Pembuat teh putih di Indonesia nampaknya bemasalah pada tidak adanya inovasi dalam pengemasan, kesadaran pembeli dan lemahnya kualitas. Penelitian ini bertujuan untuk menguji apakah pemberdayaan produk dan kesadaran merek akan mempengaruhi minat membeli produk teh putih dengan kemasan unik sebagai intervensi menggunakan partial least square sebagai metode dalam analisis data. Pengambilan sampel kuota untuk pengumpulan data menggunakan kuesioner, dengan melibatkan 50 konsumen merek teh putih di Indonesia. Bandung, Jawa Barat, Indonesia. Hasil penelitian ini menunjukkan bahwa keunikan kemasan terbukti menjadi intervensi antara kesadaran merek dan pemberdayaan dalam produk, mempengaruhi atau mempengaruhi minat beli konsumen merek teh putih di Bandung, Jawa Barat, Indonesia.

Kata kunci: produk lokal, kesadaran merek, keunikan kemasan

Bob Foster is a rector and lecturer in Fakultas Ekonomi dan Bisnis, Universitas Bisnis dan Informatika Bandung. Wawan Hermawan is a dean and lecturer in Fakultas Ekonomi, Universitas Langlangbuana Bandung Indonesia and Rima Rahmayanti is lecturer in Fakultas Bisnis \& Manajemen, Universitas Widyatama Bandung Indonesia. We are interested in marketing, retail management, branding strategies, packaging and local wisdom empowerment. 


\section{INTRODUCTION}

The empowerment of local products is being intensively carried out by the Government of Indonesia. Product empowerment activities are carried out through various media and forms of activities, one of which is through strengthening the local products themselves. The purpose of all this empowerment is the awareness of both domestic and international consumers of the existence of products. One of the products' uniqueness is obtained from product packaging. The phenomenon in Indonesia itself is often because of the absence of packaging quality understanding so that the products are not glimpsed and product awareness in the minds of consumers is low. A previous research by Dharmeria (2014) revealed the significant influence of packaging uniqueness on consumer purchasing decisions, other support obtained from research by Hidayat (2011), product packaging related to the attractiveness of a product due to dealing with consumers. The positive response from consumers was influenced by the packaging design of a product. Prabhowo (2018) also stated the same thing, that graphic design has a positive effect on impulsive buying decisions; the design structure has a positive effect on impulsive purchasing decisions.

The design of a product serves to convey the intention of the product to consumers. Consumers obtain the purpose of the product through a combination of physical appearance of the product, such as colors, shapes, and materials used. Product design also serves to create profits against the competitive pressures of a product on the market and contribute to create the product's success.

In connection with the theory above, there is phenomenon in Indonesia, local product design often fails to attract consumer awareness. A previous research carried out by Nurafina (2016) on local clothing products in Bandung, West Java, as much as $36.27 \%$ of design defects occur in local clothing products, the installation of the wrong logo. Mufreni (2016) conducted a research in tea powder industry in Indonesia. Most of the tea powder products in Indonesia are 
sold on the market using aluminum foil packaging or paper tubes coated with aluminum foil. The average tea powder producer packs its products with silver colored aluminum foil which is affixed with a simple sticker without attractive packaging rules, does not include attribute packaging including barcode, halal, household products industry number, ingredients, expiry date, production date, serving suggestion and company information. This has significantly reduced the buying interest of powder tea consumers in Indonesia. The existence of local products is very susceptible to competitiveness, especially if it does not have any uniqueness that can increase consumer awareness of the existence of these products. Related to previous data and research, this study intends to examine whether the empowerment of local products by increasing brand awareness through uniqueness of packaging can affect product purchase interest (case study in Indonesia powder tea industry, product brand: White Tea).

\section{LITERATURE REVIEW}

\section{Empowerment}

In general, empowerment is defined as a multi-dimensional social process that helps people to oversee their own lives. Carver-Managing Director of Coverdale Organization- in Clutterbuck, et. al. (1994), defines empowerment as encouraging and allowing someone to take personal responsibility to improve or improve ways to complete work so that they can contribute to achieving organizational goals. Empowerment requires the creation of a culture that encourages employees at all levels to do something different and helps employees to be confident and able to make changes. In addition to the understanding conveyed by Carver in Clutterbuck, et. al. (1994), there are several other understandings about empowerment. Yet, all the definitions that exist in principle have in common, namely that empowerment contains the following elements: 
Firstly, there is devolution of authority and responsibility for making decisions that are supported by adequate resources. Afterwards, there is control over the delegation of authority from management. There is a creation of an environment so that employees can make the most of their abilities or competencies to achieve organizational goals. Empowerment purpose is a condition experienced by the community which is characterized by the ability to think, decide and do something that is deemed appropriate to achieve the solution of the problems faced by using power.

The goal of empowerment is to form individuals and society to become independent. This independence includes independence of thinking, acting and controlling what they do. Community independence is the ability that consists of cognitive, conative, psychomotor, affective abilities, by mobilizing resources owned by the internal environment of the community.

According to Friedmann (1992), the concept of empowerment raised because of two major prizes, namely "failure" and "hope". The failure in question is the failure of the economic development model in overcoming the problem of poverty and a sustainable environment, while hope arises because of the development alternatives that incorporate democratic values, gender equality, the role between generation and adequate economic growth. On the basis of such a view, community empowerment is closely related to increasing community participation in the decision-making process in the community, so that community empowerment is closely related to strengthening, civilizing and practicing democracy.

\section{Local Brand}

According to Sudaryatmo (2011) Chair of the Indonesian Consumers Foundation (YLKI) there is indeed no clear understanding of the word local brand. However, at least four references can be used to categorize a product or brand as 
a local or not. Firstly raw materials come from local products; afterwards produced/processed domestically; then using a local brand/brand; lastly, produced by companies whose shares are owned by local investors.

\section{Brand Awareness}

According to Kotler and Keller (2012: 482) brand awareness is the ability of consumers to identify brands in different conditions, which are reflected in the brand recognition or recall performance. From the explanation above, we can describe the brand recognition scheme and brand recall as a component that plays a role in the formation of brand awareness.

Consumers usually prefer something that is considered the most familiar to them, and when consumers are aware of a brand, it is not necessarily that consumers have a preference for the brand. Yaseen, Tahira, Gulzar and Anwar (2011) state that there is no significance between brand awareness and brand loyalty. The results of the previous research say that brand awareness, perceived quality, and loyalty have an influence on purchase intention. In relation to food brand awareness, Randi (2016) examines brand awareness of Texas Chicken Pekanbaru and the effect on interests buying in fast food fried chicken. The results of research is that buying interest in Texas Chicken found a deal, which mean the respondents agree with brand image of Texas Chicken by giving good product innovation, presenting accurate in product information, competitive price and has an attractive product appearance. Buying interest of Texas Chicken Pekanbaru elevated interest.

\section{Packaging Uniqueness}

Color plays an important role in delivering cognitive messages to prospective buyer, Professor Jennifer L. Aaker in her study (1997) concluded that there were five colors that dominate the market with each cognitive note, that is light blue symbolizes sincerity, red symbolizes interest, green symbolizes competence, 
purple symbolizes establishment and yellow symbolizes endurance. The color above is not absolutely can be used as color dominance in product design, consumers with a demographic background have different tastes and perceptions different too. Study conducted by Joe Hallock (2003) in "color assignment" that consumers are either men or women like the product dominated by light blue, and do not like products with brown color. The respondents mostly are the people of Europe. In different cases, culture influence color perception such as pink is female color. While black and dark blue are male colors. Other factors that determine in product design are the selection of text or font and also photos or pictures used.

The shape of the packaging describes the size of the product packed in it. Consumers use forms as perception in determining the content or size product weight in it. Some packaging is usually larger found in dry foods, packaging it is made to be more interesting perception prospective buyers to compare products competitor. The form of packaging is very influential to the psychological potential of the consumer, with attractive packaging forms great impression will make consumers more interested to buy. This is a lot applied at certain times usually on holidays and year-end holidays. Ordinary products look better and attractive when packaged in bundle so that it seems more efficient. Together with the unique shape and appearance they will make them more attractive to consumers.

The purpose of packaging, in addition to protect, is to sell products with right packaging and design, to get potential consumer attention so that it leads to purchase process.

\section{Purchasing Interest}

Purchasing interest is characterized as the likelihood of a purchaser aiming to purchase an item. As per Ferdinand in Hakim, Susianti and Ujianto (2017: 123) purchasing interest can be recognized through pointers as takes after: 
transactional intrigue, referential intrigue, preferential interests, and interest explorative.

\section{THEORETICAL FRAMEWORK AND HYPOTHESIS}

Brand awareness will provide information about how to respond to something the brand carried out by the respondent in remembering or getting to know a brand. To measure brand awareness dimension, it is used brand recognition or recall performance as stated by Kotler and Keller (2012: 482). Kotler and Keller (2012) measures uniqueness of packaging with 6 elements that must be met when make product design that is, size, shape, material, color, text and brand. The research framework can be seen in Figure 1.

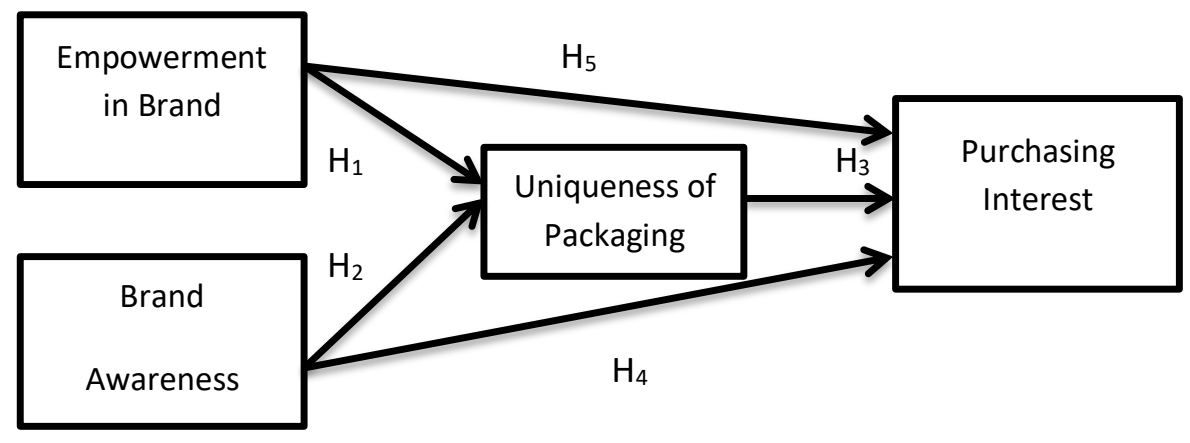

Figure 1 Theoretical framework

Source: Foster, Hermawan, Rahmayanti, 2019

Then the researcher proposed the statistical hypothesis as in Table 1.

Table 1 Hypothesis proposal

\begin{tabular}{cll}
\hline No & \multicolumn{1}{c}{ HO } & \multicolumn{1}{c}{ Ha } \\
\hline 1 & $\begin{array}{l}\text { Empowerment in Local Brand } \\
\text { affect the uniqueness of } \\
\text { packaging }\end{array}$ & $\begin{array}{l}\text { Empowerment in Local Brand } \\
\text { doesn't affect the uniqueness of } \\
\text { packaging }\end{array}$ \\
\hline 2 & $\begin{array}{l}\text { Brand Awareness of local Brand } \\
\text { affect uniqueness of packaging }\end{array}$ & $\begin{array}{l}\text { Brand Awareness of local Brand } \\
\text { doesn't affect uniqueness of } \\
\text { packaging }\end{array}$ \\
\hline 3 & $\begin{array}{l}\text { The Uniqueness of packaging } \\
\text { affect Purchasing Interest }\end{array}$ & $\begin{array}{l}\text { The Uniqueness of packaging } \\
\text { doesn't affect Purchasing Interest }\end{array}$ \\
\hline 4 & $\begin{array}{l}\text { Empowerment in Local Brand } \\
\text { directly affect purchasing } \\
\text { interest }\end{array}$ & $\begin{array}{l}\text { Empowerment in Local Brand } \\
\text { doesn't affect directly purchasing } \\
\text { interest. }\end{array}$ \\
\hline
\end{tabular}




\begin{tabular}{ll}
$\begin{array}{l}\text { Brand Awareness in Local Brand } \\
\text { directly affect purchasing }\end{array}$ & $\begin{array}{l}\text { Brand Awareness in Local Brand } \\
\text { doesn't affect directly purchasing } \\
\text { interest }\end{array}$ \\
\hline
\end{tabular}

Source: Foster, Hermawan, Rahmayanti, 2019

With the provision of:

1. $\mathrm{t}$ arithmetic $>\mathrm{t}$ table $=\mathrm{Ho}$ is not accepted and $\mathrm{H}_{1}$ accepted.

2. $\mathrm{t}$ arithmetic $<\mathrm{t}$ table $=\mathrm{Ho}$ accepted and $\mathrm{H}_{1}$ is not accepted.

\section{METHODOLOGY}

Populace inside this exploration is purchaser product: White Tea brand in Indonesia and the sample is that buyer is located in Bandung city, Indonesia. Respondent as sample in this research is a consumer of product White Tea brand in Bandung, West Java Indonesia from year of 2017. Below this is the figure of White Tea Brand packaging before and after re-package, re-design and rebranding:

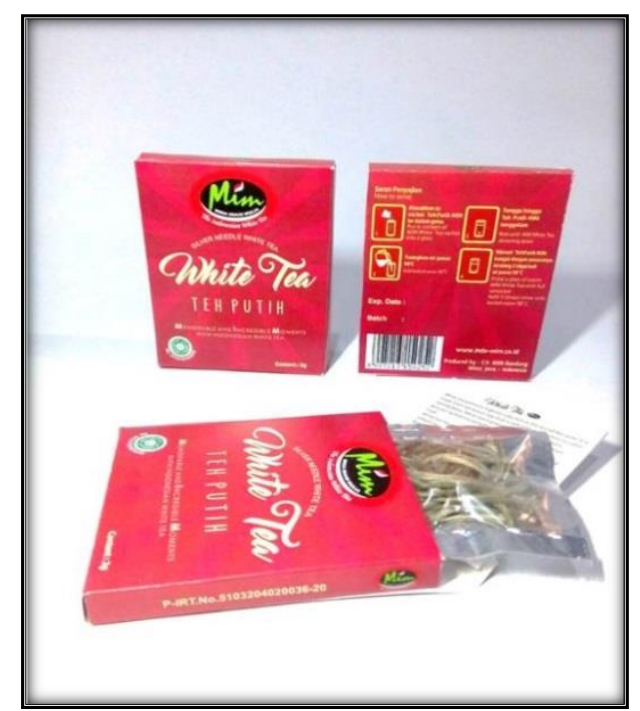

Figure 2 Design and packaging of White Tea brand Source: Foster, Hermawan, Rahmayanti, 2019 


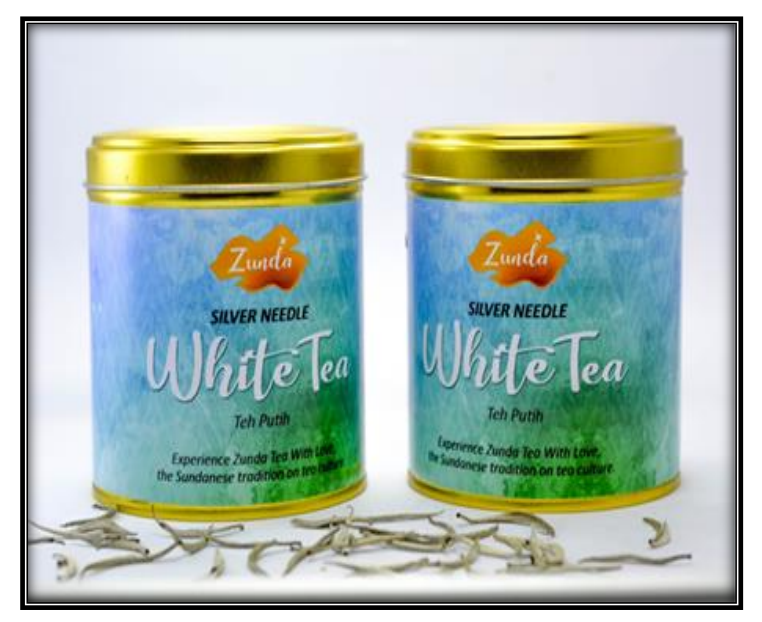

Figure 3 Design and packaging of product after rebranding, repackaging and redesigning Source: Foster, Hermawan, Rahmayanti, 2019

The number of samples identified by used of Slovin measurement as listed below:

$$
n=\frac{N}{N \cdot d^{2}+1}
$$

Where:

$\mathrm{n}=$ Number of samples

$\mathrm{N}=$ Total population $=735.000$ (box of White Tea Brand sold in Indonesia for 1 year)

$d^{2}=$ Precision (set at $10 \%$ and confidence level of $90 \%$ )

Based on this formula, the following sample sizes are obtained:

$$
\underline{n}=735.000
$$

$[735.000(0,1) 2+1]$

$\mathrm{n}=50$ consumer/ respondent. 
For information examination, legitimacy, unwavering quality and theory testing utilized in this exploration is fractional slightest square helped by XLSTAT programming for information handling. Fractional Least Square (PLS) is a piece of Structural Equation Modeling (SEM). This PLS technique is another strategy that has been generally utilized in research since it can utilize the quantity of tests less (Abdillah and Hartono, 2015).

\section{FINDINGS}

\section{Validity and Reliability Test}

Table 2 Cross-loadings (Monofactorial manifest variables)

\begin{tabular}{|c|c|c|c|c|}
\hline & Empowerment & $\begin{array}{c}\text { Brand } \\
\text { Awareness }\end{array}$ & $\begin{array}{c}\text { Uniqueness of } \\
\text { Packaging }\end{array}$ & $\begin{array}{l}\text { Purchasing } \\
\text { Interest }\end{array}$ \\
\hline Devolution & 0.937 & 0.494 & 0.670 & 0.703 \\
\hline Responsibility & 0.924 & 0.468 & 0.636 & 0.647 \\
\hline Delegation & 0.958 & 0.447 & 0.638 & 0.635 \\
\hline Independent & 0.905 & 0.377 & 0.590 & 0.607 \\
\hline Brand Recall & 0.465 & 0.961 & 0.675 & 0.666 \\
\hline \multicolumn{5}{|l|}{ Brand } \\
\hline Recognition & 0.437 & 0.950 & 0.595 & 0.654 \\
\hline Material & 0.553 & 0.574 & 0.789 & 0.576 \\
\hline Color & 0.500 & 0.441 & 0.836 & 0.532 \\
\hline Text & 0.659 & 0.593 & 0.935 & 0.782 \\
\hline Shape & 0.905 & 0.377 & 0.59 & 0.607 \\
\hline Size & 0.933 & 0.382 & 0.601 & 0.588 \\
\hline Brand & 0.577 & 0.645 & 0.854 & 0.839 \\
\hline \multicolumn{5}{|l|}{ Transactional } \\
\hline intrigue & 0.609 & 0.562 & 0.735 & 0.881 \\
\hline \multicolumn{5}{|l|}{ Referential } \\
\hline intrigue & 0.573 & 0.621 & 0.776 & 0.925 \\
\hline \multicolumn{5}{|l|}{ Preferencial } \\
\hline interests & 0.564 & 0.653 & 0.691 & 0.910 \\
\hline \multicolumn{5}{|l|}{ Interest } \\
\hline explorative & 0.716 & 0.663 & 0.741 & 0.893 \\
\hline
\end{tabular}

Source: Questionnaire running by XLStat 2018

Table 2 shows the results of data processing from questionnaires using XLSTAT software indicate the indicator in convergent validity value of each 
variable has a factor loading more than 0.50 means the statement in the questionnaire valid and can represent the variables of empowerment, brand awareness, uniqueness of packaging and purchasing interest in this study, the higher the factor loading the higher the validity.

Table 3 Composite reliability (Monofactorial manifest variables)

\begin{tabular}{cccc}
\hline Latent variable & Dimensions & $\begin{array}{c}\text { Cronbach's } \\
\text { alpha }\end{array}$ & $\begin{array}{c}\text { D.G. } \\
\text { rho } \\
\text { (PCA) }\end{array}$ \\
\hline Empowerment & 4 & 0.962 & 0.97 \\
\hline Brand Awareness & 2 & 0.946 & 0.965 \\
\hline Uniqueness of Packaging & 6 & 0.876 & 0.916 \\
\hline Purchasing Interest & 4 & 0.924 & 0.946 \\
\hline Source: Questionnaire running by XLSTAT 2018
\end{tabular}

Table 3 shows the results of data processing from questionnaires using XLSTAT software indicate that construct of each variable has a Cronbach Alpha more than 0.70 means the statement in the questionnaire reliable and can represent the variables of empowerment, brand awareness, uniqueness of packaging and purchasing interest in this study.

\section{Hypothesis Testing}

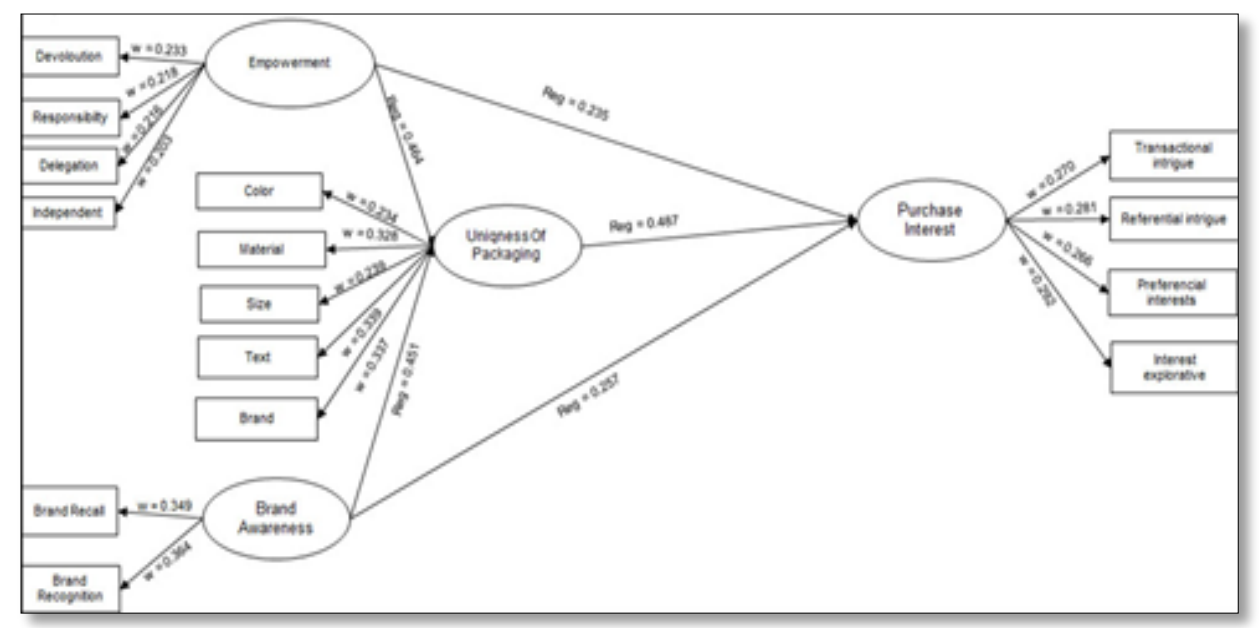

Figure 2 Hypothesis test using PLS method

Source: Foster, Hermawan, Rahmayanti, 2019 
Table 4 Inner model measure $\mathrm{R}^{2}$ (Uniqueness of Packaging)

\begin{tabular}{cccccccc}
\hline $\mathrm{R}^{2}$ & $\mathrm{~F}$ & $\begin{array}{c}\mathrm{Pr} \\
>\mathrm{F}\end{array}$ & $\begin{array}{c}\mathrm{R}^{2} \\
\text { (Bootstrap) }\end{array}$ & $\begin{array}{c}\text { Standard } \\
\text { error }\end{array}$ & $\begin{array}{c}\text { Critical } \\
\text { ratio } \\
(\mathrm{CR})\end{array}$ & $\begin{array}{c}\text { Lower } \\
\text { bound } \\
(95 \%)\end{array}$ & $\begin{array}{c}\text { Upper } \\
\text { bound } \\
(95 \%)\end{array}$ \\
\hline 0.614 & 116.877 & 0 & 0.612 & 0.084 & 7.33 & 0.425 & 0.775 \\
\hline \multicolumn{7}{c}{ Source: Questionnaire running by XLSTAT 2018}
\end{tabular}

Table 5 Path coefficients (Uniqueness of packaging)

\begin{tabular}{ccccccccc}
\hline Latent variable & Value & $\begin{array}{c}\text { Standard } \\
\text { error }\end{array}$ & $\mathrm{t}$ & $\begin{array}{c}\mathrm{Pr}> \\
\mathrm{|t|}\end{array}$ & $\mathrm{f}^{2}$ & $\begin{array}{c}\text { Value } \\
\text { (Bootstrap) }\end{array}$ & $\begin{array}{c}\text { Standard } \\
\text { error } \\
\text { (Bootstrap) }\end{array}$ & $\begin{array}{c}\text { Critical } \\
\text { ratio } \\
\text { (CR) }\end{array}$ \\
\hline Empowerment & 0.46 & 0.058 & 7.995 & 0 & 0.435 & 0.459 & 0.064 & 7.193 \\
\hline $\begin{array}{c}\text { Brand } \\
\text { Awareness }\end{array}$ & 0.45 & 0.058 & 7.773 & 0 & 0.411 & 0.452 & 0.067 & 6.711 \\
\hline \multicolumn{7}{c}{ Source: Questionnaire running by XLSTAT 2018 }
\end{tabular}

Table 4 and 5 shows that from $t$ statistic $>t$ table, where $t$ table for $n=50$ (df-2) and Alpha 0.05 is 2.013 while t statistic 7.995 for empowerment and 7.773 for brand awareness means $\mathrm{H}_{01}$ and $\mathrm{H}_{02}$ is not accepted, $\mathrm{Ha}_{1}$ and $\mathrm{Ha}_{2}$ is accepted. For $\mathrm{P}$ Value $<0.05$ that is $0.000>0.05$ means a significant variable of empowerment and brand awareness impact on uniqueness of packaging, for the impact magnitude seen in table 3 value of $R^{2}$ equal to 0.614 or $61,4 \%$.

Equation of the model:

Uniqueness of Packaging $=$

\subsection{6*Empowerment+0.450817096363599*Brand Awareness}

Table 6 Inner Model measure $\mathrm{R}^{2}$ (Purchasing interest)

\begin{tabular}{cccccccc}
\hline $\mathbf{R}^{2}$ & $F$ & $\begin{array}{c}\operatorname{Pr} \\
>\mathrm{F}\end{array}$ & $\mathrm{R}^{2}$ (Bootstrap) & $\begin{array}{c}\text { Standard } \\
\text { error }\end{array}$ & $\begin{array}{c}\text { Critical } \\
\text { ratio } \\
(\mathrm{CR})\end{array}$ & $\begin{array}{c}\text { Lower } \\
\text { bound } \\
(95 \%)\end{array}$ & $\begin{array}{c}\text { Upper } \\
\text { bound } \\
(95 \%)\end{array}$ \\
\hline $\mathbf{0 . 7 3 7}$ & 136.705 & 0 & 0.739 & 0.052 & 14.208 & 0.628 & 0.838 \\
\hline \multicolumn{7}{c}{ Source: Questionnaire running by XLSTAT 2018 }
\end{tabular}

Table 7 Path coefficients (Purchasing interest)

\begin{tabular}{|c|c|c|c|c|c|c|c|c|}
\hline Latent variable & Value & $\begin{array}{l}\text { Standard } \\
\text { error }\end{array}$ & $\mathrm{t}$ & $\begin{array}{l}\operatorname{Pr} \\
> \\
|t|\end{array}$ & $f^{2}$ & $\begin{array}{c}\text { Value } \\
\text { (Bootstrap) }\end{array}$ & $\begin{array}{l}\text { Standard } \\
\text { error } \\
\text { (Bootstrap) }\end{array}$ & $\begin{array}{l}\text { Critical } \\
\text { ratio } \\
\text { (CR) }\end{array}$ \\
\hline
\end{tabular}




\begin{tabular}{ccccccccc}
\hline Empowerment & 0.24 & 0.057 & 4.08 & 0 & 0.11 & 0.23 & 0.047 & 4.973 \\
\hline $\begin{array}{c}\text { Brand } \\
\text { Awareness }\end{array}$ & 0.26 & 0.057 & 4.52 & 0 & 0.14 & 0.254 & 0.075 & 3.426 \\
\hline $\begin{array}{c}\text { Uniqueness of } \\
\text { Packaging }\end{array}$ & 0.49 & 0.068 & 7.14 & 0 & 0.35 & 0.494 & 0.088 & 5.547 \\
\hline \multicolumn{7}{c}{ Source: Questionnaire running by XLSTAT 2018 } & &
\end{tabular}

Table 7 shows that from $t$ statistic $>t$ table, where $t$ table for $n=50$ (df-2) and Alpha 0.05 is 2.013 while t statistic for empowerment 4.084, 4.517 for brand awareness and 7.141 for uniqueness of packaging means: Firstly, $\mathrm{Ha}_{4}$ is accepted and $\mathrm{HO4}$ is not accepted, For $\mathrm{P}$ Value $<0.05$ that is $0.00<0.05$ means model significant and $t$ arithmetic $>t$ tabled (4.084>2.013) means variable of empowerment impact directly on purchasing interest.

Afterward, $\mathrm{HO}_{5}$ is not accepted and $\mathrm{Ha}_{5}$ accepted. $\mathrm{P}$ value $<0.05$ that is $0.0000<0.05$, means model significant and t arithmetic $>$ t tabled (4.517>2.013), means brand awareness impact on purchasing interest and has direct effect.

Then, $\mathrm{Ha}_{3}$ is accepted and $\mathrm{H}_{03}$ is not accepted, For $\mathrm{P}$ Value $<0.05$ that is $0.00<0.05$ means model significant and t arithmetic >t tabled (7.141>2.013) means variable of uniqueness of packaging impact directly on purchasing interest.

Equation of the model:

Purchasing Interest $=$

$0.234776820923378 *$ Empowerement $+0.257457589067245 *$ Brand Awareness $+0.487328839393392 *$ Uniqueness of Packaging.

Table 8 Direct and indirect effect

\begin{tabular}{|c|c|c|c|c|c|}
\hline & \multicolumn{3}{|c|}{ Direct Effect } & \multicolumn{2}{|c|}{ Indirect Effect } \\
\hline & Empowerment & $\begin{array}{c}\text { Brand } \\
\text { Awareness }\end{array}$ & $\begin{array}{c}\text { Uniqueness } \\
\text { of } \\
\text { Packaging }\end{array}$ & Empowerment & $\begin{array}{c}\text { Brand } \\
\text { Awareness }\end{array}$ \\
\hline Empowerment & - & & & - & - \\
\hline $\begin{array}{c}\text { Brand } \\
\text { Awareness }\end{array}$ & - & & & - & - \\
\hline $\begin{array}{c}\text { Uniqueness of } \\
\text { Packaging }\end{array}$ & 0.464 & 0.451 & - & - & - \\
\hline $\begin{array}{c}\text { Purchasing } \\
\text { Interest }\end{array}$ & 0.235 & 0.257 & 0.487 & 0.1091 & 0.1159 \\
\hline
\end{tabular}

Source: Questionnaire running by XLSTAT 2018 
Table 8 shows that this study is able to prove that the uniqueness of packaging variable is the intervening variable among empowerment, brand awareness and purchasing interest. Meanwhile, the uniqueness of packaging does not directly affect purchasing interest in large amount. According to Table 8 , it requires mediation of variable purchasing interest.

\section{CONCLUSIONS AND RECOMMENDATIONS}

The uniqueness of packaging plays an important role in mediating between product empowerment and brand trust. Manufacturers must innovate packaging so that products can increase their buying interest. Consumers are now more interested in buying products when they are attractive. Of the 50 respondents, brand awareness and brand empowerment affect buying interest. They are towards the product, but the unique packaging influences their buying interest.

Recommendations for producers are to do more in-depth research on consumers' tastes on the shape, design, material and packaging colors that will suit the target market of consumers, unique design and durable packaging is also needed to maintain product quality and meet cost effectiveness. It is intended to increase buying interest in addition to promote and strengthen products. Eventually, brand awareness will also be formed if the uniqueness of logos, fonts, colors, materials of packaging and strength of the product are embedded in consumer's mind.

\section{ACKNOWLEDGEMENTS}

We would like to express our deepest appreciation to all those who provided us the possibility to complete this paper. A special gratitude we give to our respondents and Mrs. Dian Primastuti the Marketing Director of MIM and Zunda White Tea. 


\section{REFERENCES}

Aaker, J.L., 1997. Dimensions of brand personality. Journal of Marketing Research, 34 (3), pp. 347-356.

Abdillah, W. and Hartono, J., 2015. Partial Least Square (PLS). Yogyakarta: Penerbit Andi.

Clutterbuck, D., Snow, D. and Kernaghan, S., 1994. The power of empowerment : release the hidden talents of your employees. London: Kogan Page

Carver, R., 1994. The power of empowerment David Clutterbuck and Susan Kernaghan BCA/Kogan

Dharmeria, V., 2014. Analisis pengaruh keunikan desain kemasan produk, kondusivitas store environment, kualitas display produk terhadap keputusan pembelian impulsif (studi pada Pasaraya Sri Ratu Pemuda Semarang). Jurnal Sains Pemasaran Indonesia, 8 (1), pp 1-44.

Friedmann, J., 1992. Empowerment: the politics of alternative development. Oxford: Blackwell.

Hakim, L., Susianti and Ujianto, 2017. Influence of customer relationship management, brand equity, perceived product quality, perceived price on customer value and purchase intention (Studies Philips light bulb in Batam). International Journal of Economics and Finance; 9 (7).

Hallock, J., 2003. Colour Assignment. Washington: New Media Communications. Hidayat, M.J., 2011. Tinjauan kognisi desain produk kemasan sebagai unsur identitas budaya populer atas produk kemasan makanan industri kecil menengah (IKM). Kawistara, 1(3), 213-320.

Kotler, P., \& Keller, K.L., 2012. Marketing management. Global Edition 14e. London: Pearson Education Limited. 
Mufreni, N.F., 2016. Pengaruh desain produk, bentuk kemasan dan bahan kemasan terhadap minat beli konsumen (studi kasus teh hijau serbuk tocha). Jurnal Ekonomi Manajemen, 2(2)

Nurafina, L., 2016. Analisis pengendalian kualitas dalam upaya mengurangi tingkat kegagalan produk pada usaha clothing Vocuz Evolute Bandung. Widyatama Repository.

Prabhowo, A., 2018. Analisis pengaruh keunikan desain kemasan produk terhadap keputusan pembelian impulsif (studi pada produk Kopi Good Day di Yogyakarta). UII.

Randi, 2016. Pengaruh citra merek terhadap minat beli pada makanan fast food ayam goreng (Studi pada konsumen Texas Chicken Pekanbaru). JOM FISIP, 3 (2)

Sudaryatmo, 2011. Global warming dan konsumsi produk lokal [Artikel]. Jakarta: YLKI. Available at: https://ylki.or.id/2011/11/global-warming-dan-konsumsiproduk-lokal/

Yaseen, N., Tahira, M., Gulzar, A. and Anwar, Y., 2011. Impact of brand awareness, perceived quality and customer loyalty on brand profitability and purchase intention: a resellers' view. Interdisciplinary journal of contemporary research in business, 3 (8) 